\title{
Screening of the FceRI- $\beta$-Gene in a Swiss Population of Asthmatic Children: No Association with E237G and Identification of New Sequence Variations
}

\author{
M. Rohrbach ${ }^{1, \#}$, R. Kraemer ${ }^{2}$ \\ and S. Liechti-Gallati ${ }^{1}$ \\ ${ }^{1}$ Human Molecular Genetics, Department of \\ Clinical Research, University of Berne, \\ Berne, Switzerland \\ ${ }^{2}$ Department of Paediatrics, University of \\ Berne, Berne, Switzerland
}

\begin{abstract}
BACKGROUND: The gene of the beta subunit of the high affinity receptor for IgE (FceRI- $\beta$ ) encoded on chromosome $11 \mathrm{q} 13$ has recently been identified as a candidate gene for asthma and atopy. Two coding variations, E237G and I181L have been described as being associated with asthma and atopy. Our aim was to investigate a Swiss population of atopic and asthmatic children for variations in this gene.

METHODS: We screened all 7 exons of the FceRI- $\beta$ gene in 224 atopic/asthmatic, 68 relatives and 159 control subjects using exon amplification by PCR and single strand conformation polymorphism (SSCP) analysis followed by fluorescence based DNA sequencing.

RESULTS: The sequence variant E237G was found in $3.7 \%$ in atopics and in $2.6 \%$ in the control population. None of the samples carried the I181L mutation. In addition, we characterised nine novel mutations (1 nonsense mutation, 2 missense mutations, mutation, 2 silent mutations, 4 intronic mutations).
\end{abstract}

\footnotetext{
\# Correspondence: M. Rohrbach, MD, Department of Clinical Research, Human Molecular Genetics, University of Berne, Inselspital/Kinderklinik G2/811, CH-3010 Berne, Switzerland, Tel.: +41 31632 8724, Fax: +41 31632 9484, E-mail: marianne.rohrbach@dkf2.unibe.ch
}

CONCLUSIONS: Our results suggest that the E237G does not have a primary effect on the development of atopy and asthma, and thus excludes the FceRI- $\beta$ locus from being a candidate gene directly involved in these diseases.

KEYWORDS: 11q13, atopy, BHR

\section{INTRODUCTION}

Atopic diseases such as allergic asthma, rhinitis and eczema are the most common chronic diseases encountered by paediatricians. They are characterised by genetic predisposition to produce an increased immunoglobulin $\mathrm{E}$ ( $\mathrm{IgE}$ ) response after exposure to common environmental allergens [1,2]. In addition to genetic factors there is evidence for strong environmental influence. Atopy is one of the greatest risk factors in the development of asthma [3], as identified by measurements of airway obstruction and bronchial hyperresponsiveness (BHR).

In 1989, Cookson was the first to describe linkage between IgE level and D11S97, a DNA marker sequence on chromosome 11q, in seven large, multiply affected, extended British families [4]. Transmission analysis revealed significant sharing of maternal alleles [5]. Further investigations resulted in the identification of the beta chain of the high affinity receptor for IgE (FceRI$\beta)$, localised on chromosome $11 \mathrm{q} 13$, as a candidate gene for atopy [6]. Two variants of the FceRI- $\beta$ receptor gene, the I181L in exon 6 and 
the $\mathrm{E} 237 \mathrm{G}$ in exon 7 , have been reported to be associated with atopy and asthma $[7,8,9]$.

The tetrameric high affinity receptor $\left(\alpha \beta \gamma_{2}\right)$ for IgE [10] plays a critical role in the allergic inflammation process $[11,12]$. The cross linking by allergen of $\operatorname{IgE}$ bound to the receptor on mast cells, basophils and Langerhans cells $[13,14,15]$ leads to the release of a variety of mediators and cytokines and to the manifestation of characteristic clinical symptoms. The receptor exerts positive feedback by regulation of the $\operatorname{IgE}$ production through Il-4 production by mast cells $[16,17]$. The beta chain, although without autonomous cell activation capacity, acts as an amplifier of antigen-mediated cell activation through phosphorylation of the Immunoreceptor Tyrosine-based Activation Motif (ITAM) [18].

One model used to explain the effect of mutations within the FceRI- $\beta$ is the modification of the signal transduction activity of the receptor either by producing a more sensitive receptor or by an exaggerated Il-4 release. The reported E237G, adjacent to the ITAM segment of FceRI$\beta$ changes the hydrophilic nature of the Cterminus of the beta chain and may alter the signalling capacity [8].

Several independent studies have been unable to reproduce the original linkage [reviewed in 19] or to detect the I181L polymorphism [20,21]. This negative findings either due to falsenegative PCR results [22], to variability's in phenotype definition or to complex interactions between susceptible genes and environmental factors involved in the pathogenesis of asthma [23].

Our study was designed to investigate the association of the previously reported coding variations, I181L and E237G, in a well phenotyped Swiss atopic and asthmatic population. In addition we looked for further structural changes in the FceRI- $\beta$-gene by screening the seven exons of the gene using single strand conformation polymorphism (SSCP) and direct sequencing of variants.

\section{MATERIALS AND METHODS}

\section{Subjects}

292 individuals (224 patients and 68 relatives) were recruited from the Paediatric Pulmonary Out-patient Clinic of the University Children's Hospital of Berne, Switzerland. The age of the patients ranged from 2-16 years (mean age 8.3). In total, we ascertained 45 unrelated families, 14 of these were nuclear in structure (affected child with both parents; or patient, one parent and at least one sibling), 14 sib-pairs and 179 patients without any relatives.

Informed written consent was obtained from all parents. The study was approved by the

Table 1

Association between E237G and atopy and asthma

\begin{tabular}{lccc}
\hline Proband & E237G \% (n) & $\chi^{2 \mathrm{a}}$ & $p^{\mathrm{a}}$ \\
\hline control $(\mathrm{n}=159)$ & $2.6 \%(8)$ & & \\
probands total $(\mathrm{n}=224)$ & $3.7 \%(17)$ & 1.118 & 0.29 \\
non atopic $(\mathrm{n}=88)$ & $5.2 \%(8)$ & 1.45 & 0.23 \\
atopics $(\mathrm{n}=136)$ & $2.9 \%(8)$ & 1.34 & 0.71 \\
very hihg IgE $(>1000 \mathrm{kU} / \mathrm{l})(\mathrm{n}=29)$ & $0.0 \%(0)$ & & \\
with BHR $(\mathrm{n}=47)$ & $4.2 \%(4)$ & 2.37 & 0.12 \\
no BHR $(\mathrm{n}=54)$ & $3.7 \%(4)$ & 1.12 & 0.29 \\
with Airway obstruction $(\mathrm{n}=126)$ & $3.9 \%(10)$ & 0.00 & 0.99 \\
no airway obstruction $(\mathrm{n}=60)$ & $3.3 \%(4)$ & & \\
\hline
\end{tabular}

\footnotetext{
${ }^{\mathrm{a}} \chi^{2}$ : Chisquare $p$ : $\mathrm{p}$ value (Jandel, Sigmastat Version 2.0, computerprogram)

${ }^{\mathrm{b}}$ Immunglobulin E

${ }^{\mathrm{c}}$ Bronchial hyperresponsiveness
} 
Ethical Committee of the University of Berne. All affected children had to answer an oral questionnaire on atopic and asthmatic symptoms as well as a family history questionnaire. Clinical examination of patients, performed by two independent physicians, included lung function tests, measurement of airway responsiveness to inhaled carbachol (if practicable), measurement of serum total $\operatorname{IgE}$ level and $\operatorname{IgE}$ specific antibodies for the most common allergens (birch, lye grass, house dust mite, cat and dog dander). 159 age matched randomly selected individuals of the same local population were used as a control group.

\section{Classification of subjects}

We looked for an association between variants in the FceRI- $\beta$-gene and the following two phenotypes: atopy and asthma. Atopy is defined as the presence of a specific IgE against one or more tested allergens, a high total serum $\operatorname{IgE}$ level, or a combination of these two factors [7] as well as the existence of one clinical parameter (rhinitis, eczema, allergen induced asthma, family history of atopy). Serum total $\operatorname{IgE}(\mathrm{kU} / \mathrm{l})$ was measured using the CAP system fluorimmunassay (Diagnostics CAP FEIA, Kabi Pharmacia, Sweden) and IgE for the most common allergen was determined by RAST (Diagnostics CAP FEIA, Kabi Pharmacia, Sweden). For Serum IgE, subjects were divided into two groups based on the measurements of IgE values. A high IgE level was defined as being greater than the published normal values for children [24]. 136 atopic individuals were registered (Table 1).

The asthmatic phenotype was defined by the presence of significant reversible obstruction of airways and/or bronchial hyperresponsiveness (BHR) to inhaled carbachol as well as by documented history of recurrent wheeze and cough [25].

Lung function testing was performed by whole-body plethysmography [26,27], using an air conditioned, constant volume, variable pressure whole-body plethysmograph (Jaeger, Würzburg, Germany). The thoracic gas volume
(TGV) was taken as an estimate of degree of pulmonary hyperinflation. Lung function data were expressed as a percent of predicted values [28]. As an estimate of bronchial obstruction the airway resistance $\left(\mathrm{R}_{\mathrm{aw}}\right)$, measured during quiet breathing, the forced expiratory resistance volume (flow-volume curves) in one second $\left(\mathrm{FEV}_{1}\right)$ and the maximal expired flow at $50 \%$ of vital capacity $\left(\mathrm{MEF}_{50}\right)$ (flow-volume curves) were taken. Bronchial obstruction was defined as $\mathrm{R}_{\mathrm{aw}}>130 \%$ or $\mathrm{MEF}_{50}<80 \%$ [26]. Bronchial responsiveness was assessed by bronchial challenge test with carbachol chloride (Bronchoscreen, Jaeger, Würzburg, Germany). BHR was presumed to be present when the cumulative provocation dose of carbachol induces a rise of $\mathrm{R}_{\mathrm{aw}}>165 \%$ of initial value $\left(\mathrm{PD}_{65}\right)$ was $<480 \mu \mathrm{g}[29,30]$. Patients were divided into four groups, relative to BHR and bronchial obstruction (Table 1).

\section{Genotyping}

Genomic DNA was isolated according to standard protocols and quantified by spectrophotometry. PCR amplifications were carried out in $50 \mu \mathrm{l}$ reaction volumes (Perkin Elmer, Thermal cycler 2400, Oak Brook, Il) containing $100-200 \mathrm{ng}$ of genomic DNA, 10 pmol of each primer, $50 \mathrm{mM} \mathrm{KCl}, 1.5 \mathrm{M}$ $\mathrm{MgCl}, 10 \mathrm{mM}$ Tris-HCl pH 8.3, $10 \mathrm{mM}$ dNTP and $2.5 \mathrm{U}$ Taqpolymerase Gold (Perkin Elmer). The samples were denatured for $12 \mathrm{~min}$ at $95^{\circ} \mathrm{C}$, followed by 28 cycles each of $15 \mathrm{~s} 95^{\circ} \mathrm{C}$ denaturation, $15 \mathrm{~s} 58^{\circ} \mathrm{C}$ annealing, $45 \mathrm{~s} 72{ }^{\circ} \mathrm{C}$ extension. Final extension was at $72{ }^{\circ} \mathrm{C}$ for $7 \mathrm{~min}$. Primers used to amplify the 7 exons of the FceRI- $\beta$-gene are listed in Table 2.

$2 \mu 1$ of PCR products were denatured at $95^{\circ} \mathrm{C}$ for 10 min with $3 \mu 1$ SSCP loading buffer $(0.2 \mathrm{M}$ $\mathrm{NaOH}, 0.25 \% \mathrm{w} / \mathrm{v}$ each bromphenol blue and xylene cyanol in formamide) and analysed on a polyacrylamide gel containing glycerol using a two-buffer system [39]. DNA was visualised by silver staining. PCR products producing band shifts in either single (SSCP) or double strands (heteroduplex formation) were purified using PCR purification columns (High Pure ${ }^{\mathrm{TM}}$ PCR 
Table 2

Amplification Primer sequences (Hill, 1996) for the amplification of the 7 exons of the FceRI- $\beta$-gene

\begin{tabular}{|c|c|c|c|c|}
\hline Exon & Proximal primer $5^{\prime} \rightarrow 3^{\prime}$ & Distal primer $5^{\prime} \rightarrow 3^{\prime}$ & $\begin{array}{c}\text { PCR } \\
\text { fragment (bp) }\end{array}$ & $\operatorname{SSCP}(\%)$ \\
\hline 1 & GCCTGTTGATCTTAATCAGC & AGTTTCATCTCCTAAGCACC & 323 & 8 \\
\hline 2 & TCTGTCTGTCGAGAATGTTG & GACCTAACACCTCTCATGAA & 309 & 10 \\
\hline 3 & CGCAGTTTCTCATGTTTGGC & CTGGTTAGATCTGAGAAAGAG & 322 & 8 \\
\hline 4 & GTAACTTTATCGAGTACCCC & GCAAAAAGCCTTAGGACACA & 321 & 8 \\
\hline 5 & CCAGCCCTGAAATGAAGATA & AGGATGGTGTTCATGGAACA & 329 & 8 \\
\hline 6 & GGAGATGAAAACAGGAGATG & GTTTCAGAAAACCCAGGCC & 242 & 8 \\
\hline 7 & GATGAGGTAAGTCTCTTGAG & CAAAACCTTGGCCTTCTGG & 239 & 10 \\
\hline
\end{tabular}

All primers were synthesised by Microsynth (Balgach, Switzerland)

Product Purification Kit, Boehringer) according to the suppliers recommendations, followed by fluorescence based sequencing (ABI373, Perkin Elmer). Sequences were analysed by SeqEd program (Applied Biosystem) and compared to the FceRI- $\beta$-gene sequence (GenBank, M89796).

\section{Reverse transcription PCR}

Total RNA was extracted from blood cells according to Chomczynski and Sacchi [31]. Reverse transcription was performed using commercial reagents (Boehringer Mannheim, Expand $^{\mathrm{TM}}$ Reverse Transcriptase) with initial incubation of template RNA and primer FEE7b (5'-CAAAACCTTGGCCTTCTGG-3', [8]) for 10 min at $65^{\circ} \mathrm{C}$, followed by $60 \mathrm{~min}$ at $42^{\circ} \mathrm{C}$ for cDNA synthesis. The cDNA was amplified in a $50 \mu 1$ reaction volume using a primer set flanking the nonsense mutation (exon 4-exon 7): proximal primer 5'-AGGAGAAATGCAACATATCTG-3' (newly designed) and distal primer 5'CAAAACCTTGGCCTTCTGG-3'. PCR conditions are as described above. PCR products were analysed on $12 \%$ SSCP gels and sequenced as described above.

\section{Restriction digest}

RT-PCR products enclosing exon 4-exon 7 were digested with MaeIII according to the manufacturer's instructions (Boehringer Mannheim, 822230). cDNA was incubated for 1 $\mathrm{h}$ at $55^{\circ} \mathrm{C}$ with $2 \mathrm{x}$ MaeIII buffer and 1 Unit restriction enzyme, MaeIII. The resulting products were separated on $12 \%$ SSCP gels.

\section{RESULTS}

All 7 exons of the FceRI- $\beta$-gene were screened for sequence variations using PCR amplification including the intron/exon boundaries. The published sequence of Küster and Kinet [32] was used as reference sequence. 451 individuals were screened for sequence variations using single strand conformation polymorphism (SSCP)
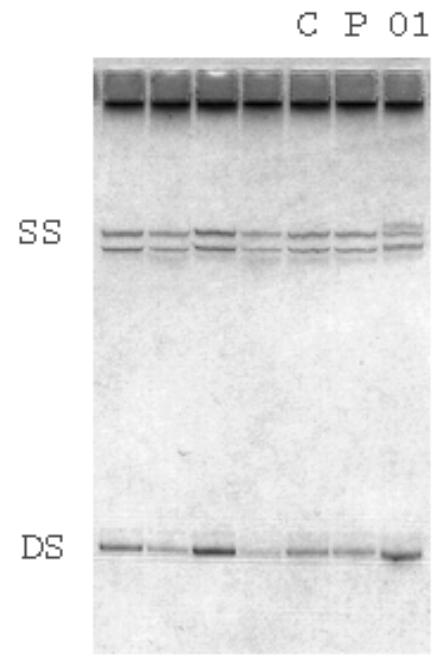

Fig. 1a. SSCP gel analysis of PCR product exon 6. SS stands for single strands, DS for double strands, $\mathrm{C}$ for PCR positive control, and $\mathrm{P}$ for wildtype control. 01 shows a band migration in the SS and DS and carries the nonsense mutation, G192X. 
Table 3

FceRI- $\beta$ variants identified in 224 (448 chromosomes) patients and 159 (318 chromosomes) controls

\begin{tabular}{ccccc}
\hline Nucleotide change & Aminoacid change & Exon & frequency $\%$ & control frequency \% \\
\hline $457 \mathrm{~T} \rightarrow \mathrm{G}$ & M1R & 1 & 0.2 & 0 \\
$2130 \mathrm{~A} \rightarrow \mathrm{G}$ & none & 3 & 0.2 & 0 \\
$5676 \mathrm{G} \rightarrow \mathrm{T}$ & $\mathrm{G} 192 \mathrm{X}$ & 6 & 0.2 & 0 \\
$5691 \mathrm{G} \rightarrow \mathrm{A}$ & $\mathrm{V} 197 \mathrm{M}$ & 6 & 0 & 1.3 \\
$7256 \mathrm{C} \rightarrow \mathrm{T}$ & none & 7 & 0.45 & 0 \\
$7297 \mathrm{~A} \rightarrow \mathrm{G}$ & $\mathrm{E} 237 \mathrm{G}$ & 7 & 3.7 & 2.6 \\
\hline
\end{tabular}

Table 4

Intronic sequence variants

\begin{tabular}{cccc}
\hline Nucleotide change & Intron & frequency $\%$ & control frequency $\%$ \\
\hline Exon $4-87$ T to G & 3 & 31.6 & 28.5 \\
Exon 4 + 11 C to T & 4 & 0.2 & 0 \\
Exon 4 + 37 A to G & 4 & 1.7 & 1.3 \\
Exon 6 - 12 G to A & 5 & 0.4 & 0 \\
\hline
\end{tabular}

analysis (Figure 1a and 4). PCR products with irregular band migration were subjected to sequencing.

The substitution of glutamic acid for glycin at residue 237 (E237G), was recently reported in $5.3 \%$ and $6 \%$ in an Australian [8] and Japanese [9] population, respectively and described as being strongly associated with asthma and atopy. We found the E237G variant in 17 out of 448 chromosomes $(3.7 \%)$ of our selected Swiss asthma and atopy population and in 8 out of 318 control chromosomes $(2.6 \%)$ (Table 3 ). No homozygous individual for $\mathrm{E} 237 \mathrm{G}$ was found in a total of 451 persons screened. Among 136 atopic patients $2.9 \%$ showed the $\mathrm{E} 237 \mathrm{G}$ variant, whereas $5.2 \%$ of non-atopic patients carried the mutation (Table 1). Compared to the control group there was no association of E237G with atopy $(\operatorname{IgE}<1000 \mathrm{kU} / \mathrm{l}) \quad\left(\chi^{2}=1.34 ; \mathrm{p}=0.71\right)$, with very high $\operatorname{IgE}$ levels (IgE $>1000 \mathrm{kU} / \mathrm{l})$ $\left(\chi^{2}=1.00 ; p=0.317\right)$ (Table 1) or with one of the tested specific allergens, as previously reported [7,8]. No significant relation between E237G and the asthmatic phenotype was observed (BHR: $\chi^{2}=0.02 ; p=0.866 /$ Airway obstruction: $\left.\chi^{2}=0.00 ; p=0.99\right)$ (Table 1). Of fourteen atopic or asthmatic sibpairs only one sibling carried the E237G. Inheritance of FceRI- $\beta$-alleles through the maternal lines were reported to increase the genetic risk for atopy and BHR [5,33]. Controversial, transmission analysis of the E237G allele in 4 affected nuclear Swiss families indicated no maternal effect. All 3 children who had inherited the allele E237G paternal were atopic including elevated $\mathrm{IgE}$, rhinitis and asthma. In contrast the E237G allele of a healthy mother was not transmitted to her affected son. Thus, a predominant inheritance through maternal line can be excluded.

Using both SSCP and direct sequencing of purified PCR fragments enclosing exon 6 we were not able to detect the I181L polymorphism described by Shirakawa et al. [7].

Moreover, we identified heterozygosity for 9 different mutations: one nonsense, one start codon, one missense, two silent mutations and four intronic polymorphisms (Table 3 and 4).

A start codon mutation at nt $457 \mathrm{~T} \rightarrow \mathrm{G}$ was found in one atopic patient (Table 3). It was the only mutation identified in the coding region of exon 1. The two silent mutations were found in exon $3(2130 \mathrm{~A} \rightarrow \mathrm{G})$ and in exon $7(7256 \mathrm{C} \rightarrow \mathrm{T})$, in one and two patients, respectively (Table 3 ).

A single nonsense mutation located at nt $5676 \mathrm{G} \rightarrow \mathrm{T}(\mathrm{G} 192 \mathrm{X})$ in exon 6 was detected in two relatives (atopic patient and atopic father) (Table 3, Figure 1a and 1b). This mutation creates a new restriction site for MaeIII. Exon 
A

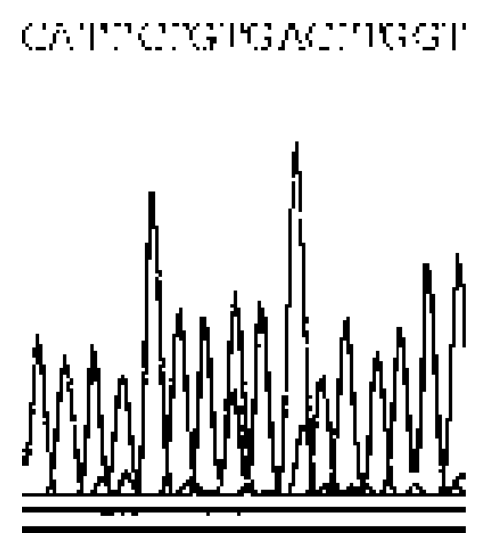

$\mathrm{B}$

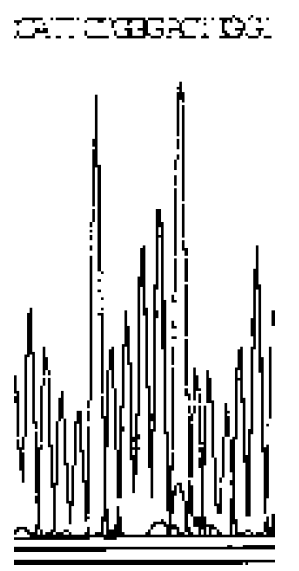

Fig. 1b. Automated sequence analysis, ABI373, Perkin Elmer, of a purified exon 6 PCR product. A: shows heterozygosity for a G to T substitution (G192X). B: shows the sequence of a wildtype sequence of exon 6 .

skipping of exon 6 was excluded by RT-PCR amplifying exon 4-exon 7 and direct sequencing of the corresponding cDNA (Figure 2). RT-PCR from RNA extracted from blood lymphocytes of these two individuals followed by MaeIII restriction of the corresponding cDNA showed no additional restriction product (Figure 3). Thus, the mutation was not detectable on mRNA level.

We tested all exons in at least 318 control chromosomes under the same PCR and SSCP conditions (Table 3 ). Only the previously reported sequence variation E237G and a missense mutation in exon 6 were identified in control chromosomes (Table 3 ).

We found four intronic polymorphisms (Table 4) concentrated in three regions: intron 3, intron 4 and intron 5. The frequent exon 4-87 T to $\mathrm{G}$ polymorphism (Figure 4) is located near the acceptor splice site of exon 4 , but it is unlikely to affect the splicing efficiency. $31 \%$ of patients and $28.5 \%$ of controls are homozygous for this variant, whereas only $16 \%$ and $17 \%$, respectively, were homozygous for the published wildtype T. The heterozygous proportion is about 53\% in both populations. The Hardy Weinberg equilibrium is fulfilled with this distribution (patients: $\quad \mathrm{p}=0.34 ; \quad \mathrm{q}=0.18$ / controlgroup: $p=0.30 ; q=0.19$ ). No significant association between atopy or BHR and one of the three genotypes was detected. The remaining three intronic polymorphisms (intron 3, 4, 5) are very rare, $0.2 \%-1.7 \%$ (Table 4 ), and none of them influence splicing elements.

\section{DISCUSSION}

The tetrameric $\left(\alpha \beta \gamma_{2}\right)$ high affinity receptor for IgE, FceRI, plays a central role in the process of IgE-dependent allergic inflammation [11]. A sequence variant, E237G, in the gene for the beta subunit of the high affinity receptor for IgE (FceRI- $\beta$-gene) has recently been reported to be associated with BHR and high IgE levels in an Australian and Japanese population $[8,9]$.

The aim of our study was to screen 242 unrelated patients, 68 relatives and 159 controls for the complete coding sequence of the FceRI- $\beta$ gene, which encodes a 244 amino acid beta subunit of the tetrameric high affinity receptor for IgE, using SSCP. The E237G mutation was identified in $3.7 \%$ of our selected Swiss atopy/asthma population and in $2.6 \%$ of the control group (Table 3). Statistical evaluation showed no evidence of higher prevalence of E237G in atopics or asthmatics compared to the control population and non asthmatics, respectively (Table 1). Transmission analysis of E237G was performed in order to take account of 


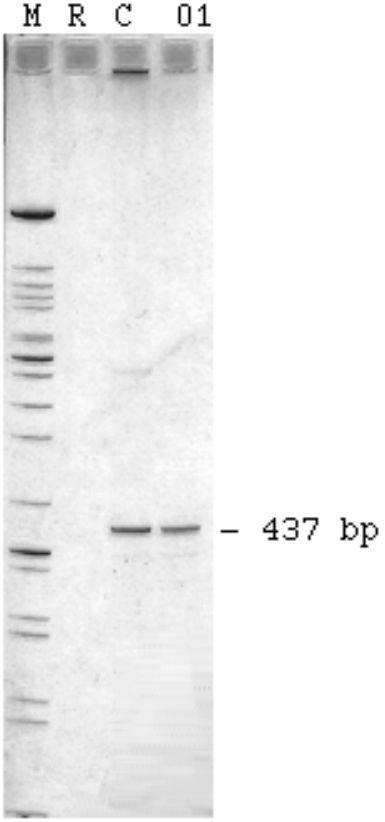

Fig. 2. Gel analysis of RT-PCR exon 4-exon 7. $\mathrm{R}=\mathrm{PCR}$ reagents control, $\mathrm{C}=$ control person, and $\mathrm{M}=$ size marker. The size of PCR products without exon skipping is expected to be $437 \mathrm{bp}$, whereas exon skipping would produce a $338 \mathrm{bp}$ fragment. PCR product of index patient 01, carrying one G192X, shows the same size as C. An exon skipping of exon 6 can be excluded.

the suggested increased atopy risk in the presence of maternal inheritance [5,33]. The phenotyp expression of an 11q13 locus did not depend on maternal inheritance in our Swiss asthma population. Thus, our results exclude $\mathrm{E} 237 \mathrm{G}$ from having a primary effect on the development of atopy and asthma, however a secondary pathogenic influence in combination with another mutation cannot yet be excluded, since it is located adjacent to the Immunoreceptor Tyrosine-based Activation Motif (ITAM). The ITAM segment is involved in amplifying the tetrameric FceRI receptors allergic cell activation [18] in human mast cells and basophils. A mutation located nearby the ITAM could influence the cell signalling by modifying the amplifier function. To evaluate the effect of a mutation within this region, a cultured cell model for human Fc receptor is under construction [34]

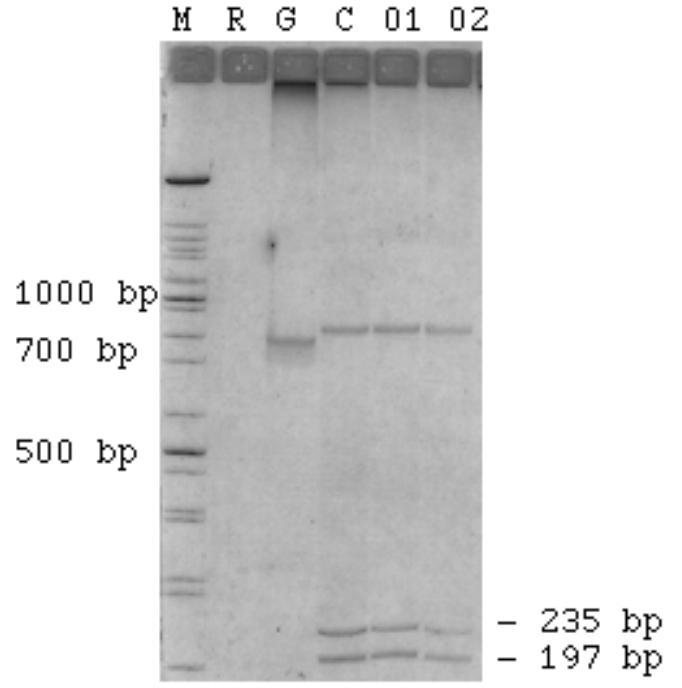

Fig. 3. Gel analysis of RT-PCR exon 4-exon 7 after digestion with MaeIII from the two relatives with the nonsense mutation, $\mathrm{G} 192 \mathrm{X}(01,02)$, and from a control (C). $\mathrm{R}=\mathrm{PCR}$ reagents control, $\mathrm{G}=$ genomic DNA control, $\mathrm{M}=$ size marker (100 bp marker). Restriction with MaeIII creates two digestion products (197 and $235 \mathrm{bp}$ ) in wildtype mRNA and three products in mutated mRNA $(20,197$ and $215 \mathrm{bp})$ are expected. Patients 01 and 02 show the same digestion pattern as the control.

and will give insights into functional consequences of sequence variations.

Another variant of the FceRI- $\beta$-gene associated with atopy, I181L in exon 6 , has been reported in a UK (17\%) population [7]. We did not detect any $\mathrm{I} 181 \mathrm{~L}$ carrier in 902 screened chromosomes. This is in agreement with several other investigations [reviewed in 23]: 12 out of 15 investigations analysing different ethnic populations and using a variety of different methodologies, did not find the mutation within exon 6. Regarding our screening system, it is very unlikely that we missed the $1181 \mathrm{~L}$ due to methodological failure because: 1) By screening 902 chromosomes with a newly developed, highly sensitive SSCP technique [39] around exon 6 we were able to identify three rare polymorphisms, but not the I181L. Moreover, a portion of PCR products of exon 6 were directly 


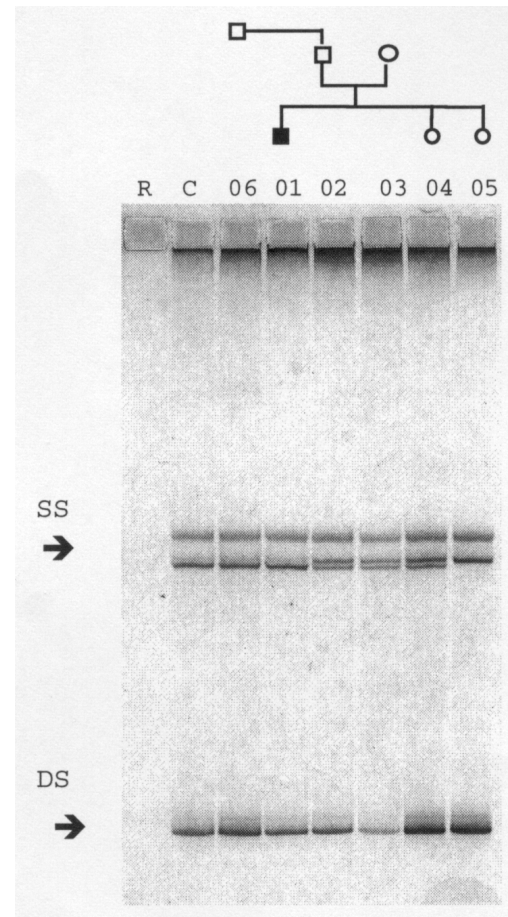

Fig. 4. SSCP analysis of FceRI- $\beta$ exon 4 variant (exon 4-87 $\mathrm{T}$ to $\mathrm{G}$ ) in an atopic family (6 members), with index patient $01 . \mathrm{SS}=$ single strands, $\mathrm{DS}=$ double strands, $\mathrm{R}=\mathrm{PCR}$ reagents control, $\mathrm{C}=\mathrm{PCR}$ positive control. Family member $02,03,04$ represent the heterozygous band migration in SS. Member 05 shows normal band migration, C, 01 and 06 represent homozygosity for $\mathrm{G}$.

sequenced in order to exclude a SSCP failure. 2) A microsatellite repeat near to the start of exon 6, thought to be responsible for false-negative PCR products [22], was not enclosed in our exon 6 PCR amplification.

We suggest therefore that this $1181 \mathrm{~L}$ mutation is a rare polymorphism and an involvement in the development of asthma and atopy is rather unlikely.

In addition, we report here a nonsense mutation within exon 6, G192X, found in two relatives (Table 3, Figure 1a and $1 \mathrm{~b}$ ). Our results indicate instability of the corresponding mRNA because we could not detect this mutation on cDNA level, using restriction with MaeIII (Figure 3). This makes a protein truncation very unlikely. In any case, a nonsense mutation is expected to result in a loss of function or reduction of the beta subunit of FceRI. Since variations in the FceRI- $\beta$ promote the atopic state by enhanced release of inflammatory mediators by mast cells; a loss of function mutation would not explain an atopic phenotype. Even though the nonsense mutation is not responsible for atopy, it might be of importance for functional studies of the beta subunit.

Heterozygosity for the widespread intron 3 substitution (exon 4-87 T to G) (Table 3 and Figure 4) was found in $53 \%$ of both patients and controls. The higher prevalence of homozygosity for $\mathrm{G}$ in both groups indicates that the $\mathrm{G}$ allele is more likely to be the wildtype sequence. There was no relation found between one of the three genotypes $(\mathrm{G} / \mathrm{G}, \mathrm{G} / \mathrm{T}, \mathrm{T} / \mathrm{T})$ and asthma or atopy. This frequent polymorphism may be useful for further linkage analysis studies, since association between IgE and BHR and the markers D11S527 and D11S534 telomeric to FceRI- $\beta$ has been reported [35].

We found two silent mutations (Table 3), located within the coding region of the FceRI- $\beta$ gene. We did not investigate in the corresponding RNA, because synonymous changes are not supposed to be pathogenic. However, some caution must be kept in considering these synonymous mutations as neutral, because they might hide cryptic splice sites [36] and/or affect mRNA stability.

In summary, we characterised 9 novel variants and the previously reported $\mathrm{E} 237 \mathrm{G}$ mutation within the gene for the beta subunit of the high affinity receptor for IgE (Table 3 and 4). None of them showed a significant association with either atopy or asthma phenotype giving no explanation for the strength of chromosome 11q13 linkage (Table 1), that has been revealed in two very recent genome-wide screens in families from different racial groups [37,38].

Our findings are not yet surprising since there is little doubt that the susceptibility of developing asthma or atopy is influenced not only by one, but by multiple genes that may interact with each other and with environmental factors determining the asthmatic or atopic phenotype. It is unlikely that a single cell type, mediator or cytokine involved in the allergic cascade accounts for all 
of the features of allergic inflammation. Novel regions of interest have been identified using genome screening [37,38], which have to be characterised. Further investigations including gene-gene and gene-environment interactions, and a generally accepted phenotype definition will be necessary to understand the complex molecular mechanisms underlying asthma and atopy. The knowledge of these mechanisms will open a variety of potential diagnostic and therapeutic avenues.

\section{Acknowledgments}

We would like to thank Dr. Ch. Mamie, Dr. U. Frey and Dr. A. Schibler for their collection and phenotyping of subjects and H. Fankhauser, H. Staub and C. Erb for technical lung function assistance. This work has been supported by the Silva Casa Foundation Grant No. 44-313. All described experiments comply with the current law in Switzerland.

\section{References}

[1] Ishizaka, K. Mechanism of reaginic hypersensitivity. Clin. Allergy 1, (1971) 9-24.

[2] Leung, D.Y.M. Mechanisms of the human allergic response; clinical implications. Pediatr. Clin. North Am. 41, (1994) 727-743.

[3] Sears, M., Burrows, B., Flannery, E.M., Herbison, G.P., Hewitt, C.J. and Holdaway, M.D. Relation between airway responsiveness and serum IgE in children with asthma and apparently normal children. N. Engl. J. Med. 325, (1991) 1067-1071.

[4] Cookson, W.O., Sharp, P.A., Faux, J.A. and Hopkin, J.A. Linkage between immunoglobulin E response underlying asthma and rhinitis and chromosome 11q. Lancet 1, (1989) 1292-1294.

[5] Cookson, W.O., Young, R.P., Sandford A.J. et al. Maternal inheritence of atopic IgE responsiveness on chromosome 11q. Lancet 340, (1992) 381-384.

[6] Sandford, A.J., Shirakawa, T., Moffat, M.F., Daniels, S.E., Faux, J.A., Young, R.P., Nakamura, Y., Lathrop, G.M., Cookson, W.O.C.M. and Hopkin, J.M. Localization of atopy and $\beta$ subunit of high affinity $\operatorname{IgE}$ receptor (FceRI- $\beta$ ) on chromosome 11q. Lancet 341, (1993), 332-334.

[7] Shirakawa, T., Li, A., Dubowitz, M., Dekker, J.W., Shaw, A.E., Faux, J.A., Ra, C., Cookson, W.O.C.M. and Hopkin, J.M. Association between atopy and variants of the high affinity immunglobulin E receptor. Nature Genet. 7, (1994) 125-130.

[8] Hill, M.R. and Cookson, W.O.C.M. A new variant of the $\beta$ subunit of the high affinity receptor for Immunoglobulin $\mathrm{E}$ (FceRI- $\beta$ E237G): association with measures of atopy and bronchial hyperresponiveness. Hum. Mol. Genet. 5, (1996) 959-962.

[9] Shirakawa, T., Mao, X.Q., Sasaki, S., Enomoto, T., Kawai, M., Morimoto, K. and Hopkin, J. Association between Atopic Asthma and a coding variant of FceRI- $\beta$ in a Japanese population. Hum. Mol. Genet. 5, (1996) 11291130.

[10] Blank, U., Ra, C., Miller, L., White, K., Metzger, H. and Kinet, J.P. Complete structure and expression in transfected cells of high affinity IgE receptor. Nature 337, (1989) 187-189.

[11] Dombrowicz, D., Flamand, V., Brigman, K.K., Koller, B.H. and Kinet, J.P. Abolition of anaphylaxis by targeted disruption of the high affinity immunoglobulin $\mathrm{E}$ receptor alpha chain gene. Cell 75, (1993) 969-976.

[12] Ravetch, J.V. Atopy and Fc receptors: mutation is the message? Nat. Genet. 7, (1994) 117-120.

[13] Kinet, J.P., Metzger, H., Hakimi, J. and Kochan, J.A. cDNA presumptively coding for the alpha subunit of the receptor with high affinity for immunglobulin E. Biochemistry 26, (1987) 46054610.

[14] Kochan, J., Pettine, L.F., Hakimi, J., Kishi, K. and Kinet, J.P. Isolation of the gene coding for the alpha subunit of the high affinity $\operatorname{IgE}$ receptor. Nucleic Acids Res. 16, (1988) 3584.

[15] Ravetch, J.V. and Kinet, J.P. Fc receptors. Ann. Rev. Immunol. 9, (1991) 457-492.

[16] Plaut, M., Pierce, J.H., Watson, C.J., HanleyHyde, L., Nordan, R.P. and Paul, W.E. Mast cell lines produce lymphokines in response to crosslinkage of FceRI or to calcium ionophores. Nature 339, (1989) 64-67.

[17] Schroeder, J.T., MacGlashan, D.W., KageySobotka, A., White, J.M. and Lichtenstein, L.M. IgE-dependent Il-4 secretion by human basophils: the relationship between cytokine production and histamine release in mixed leukocyte cultures. $J$. 
Immunol. 153, (1994) 1808-1817.

[18] Lin, S., Cicala, C., Scharenberg, A.M. and Kinet, J.P. The FceRI- $\beta$ subunit functions as an amplifier of FceRI- $\beta$-mediated cell activation signals. Cell 85, (1996) 985-995.

[19] Sandford, A.J., Weir, T. and Paré, P. The genetics of asthma. Am. J. Repir. Crit. Care Med. 153, (1996) 1749-1765.

[20] Hizawa, N., Yamaguchi, E., Furuya, K., Ohnuma, N., Kodama, N., Kojima, J., Ohe, M. and Kawakami, Y. Association between high serum total IgE levels and D11S97 on chromosome 11q13 in Japanese subjects. J. Med. Genet. 32, (1995) 363-369.

[21] Duffy, D.L., Healey, S.C., Chenevix-Trench, G., Martin, N.G., Weger, J. and Lichter, J. Atopy in Australia. Nat. Genet. 10, (1995) 260.

[22] Hill, M.R. and Cookson, W.O. Atopy in Australia. Correspondence. Nat. Genet. 10, (1995) 260.

[23] Thomas, N.S., Wilkinson, J. and Holgate, S.T. The candidate region approach to genetics of asthma and allergy. Am. J. Respir. Crit. Care Med. 156, (1997) 144-151.

[24] Björksten, B. and Weeke, B. Allergy 40, (1985) Suppl 4.

[25] Ritter, C., Bättig, M., Kraemer, R. and Stadler, B.M. IgE hidden in immune complexes with antiIgE autoantibodies in children with asthma. $J$. Allergy Clin. Immunol. 88, (1991) 793-800.

[26] Kraemer, R., Meister, B., Schaad, U.B. and Rossi, E. Reversibility of lung function abnormalities in children with perennial asthma. J. Pediatrics 102, (1983) 347-350.

[27] Kraemer, R., Sennhauser, F.H. and Reinhardt, M. Effects of regular inhalation of beclomethasone dipropionate and sodium cromoglycate on bronchial hyperreactivity in asthmatic children. Acta Paediatr. Scand. 76, (1987) 119-123.

[28] Zapletal, A., Samanek, M. and Paul, T. Lung function in children and adolesents. Methods, Reference Values. Prog. Respir. Res. 22, (1987) 113-218.

[29] Wirz, C., Frey, U., Schöni, M. and Kraemer, R. Specific approach on dose-response curves to inhaled Carbachol assessed by the interruption technique in children. Pediatr. Research 34, (1993) 478-484.

[30] Kraemer, R., Wirz, C., Gschwend-Eigenmann, S., Schöni, M.H. and Stadler, B.M. Interfering factors to sensitivity and specificity of bronchial reactivity in children. Pediatr. Allergy Immunol. 4, (1993) 187-195.

[31] Chomczynski, P. and Sacchi, N. Single step method of RNA isolation by acid guanidium thiocyanate-phenol-chlorophorm extraction. Anal. Biochem. 162, (1987) 165-159.

[32] Küster, H., Zang, L., Brini, A., MacGalshan, D.W.J. and Kinet, J.P. The gene and cDNA for the human high affinity immunglobulin $\mathrm{E}$ receptor $\beta$ chain and expression of the complete human receptor. J. Biol. Chem. 267, (1992) 12782-12787.

[33] Hill, M.R., James, A.L., Faux, J.A., Ryan, G., Hopkin, J.M., le Souef, P., Musk, A.W. and Cookson, W.O.C.M. FceRI- $\beta$ polymorphism and risk of atopy in a general population sample. BMJ 311, (1995) 776-779.

[34] Scharenberg, A.M. and Kinet, J.P. Fc epsilon RI and the FcR-Beta Amplifier. Int. Arch. Allergy Immunol. 113, (1997) 42-44.

[35] Doull, I.J., Lawrence, M.S., Watson, M., Beghishvili, T., Beasley, R.W., Lampe, F., Holgate, S.T. and Morton, N.E. Allelic association of gene markers on chromosomes $5 \mathrm{q}$ and $11 \mathrm{q}$ with atopy and bronchial hyperresponsiveness. Am. J. Respir. Crit. Care Med. 155, (1996) 1280-1284.

[36] Richard, I. and Beckmann, J. How neutral are synonymous codon mutation? Nat. Genet. 10, (1995) 259.

[37] Collaborative study of the genetics of asthma (CSGA). A genome-wide search for asthma susceptibility loci in ethnically diverse populations. Nat. Genet. 15, (1997) 389-397.

[38] Daniels, S.E., Bhattacharrya, S., James, A., Leaves, N.I., Young, A., Hill, M.R., Faux, J.A., Ryan, G.F., Le Souef, P.N., Lathrop, G.M., Musk, A.W. and Cookson, W.O. A genome-wide search for quantitative trait loci underlying asthma. Nature 383, (1996) 247-250.

[39] Liechti-Gallati, S. et al. Eur. J. Genet. in press. 


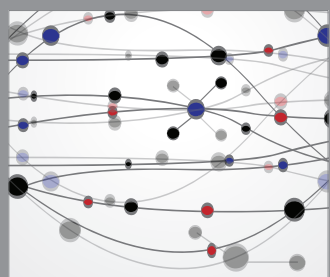

The Scientific World Journal
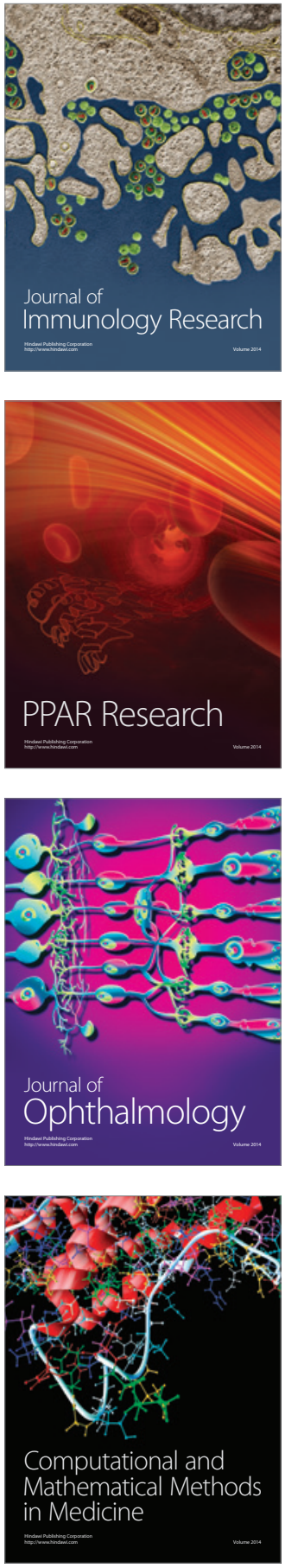

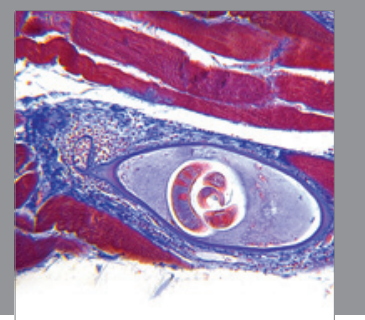

Gastroenterology

Research and Practice
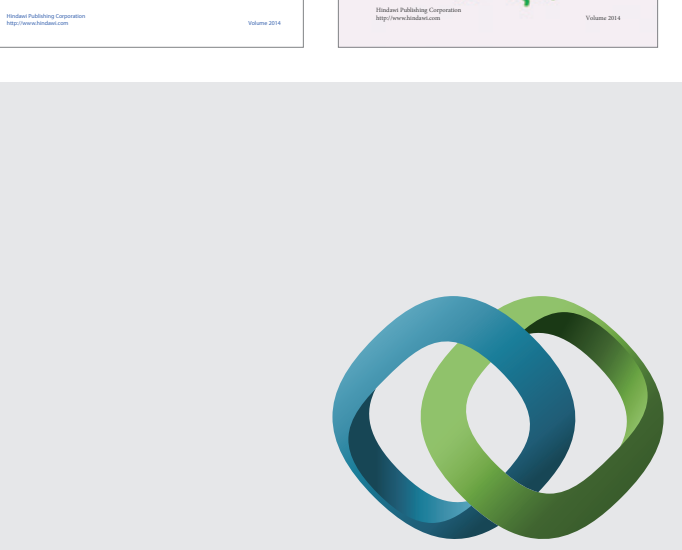

\section{Hindawi}

Submit your manuscripts at

http://www.hindawi.com
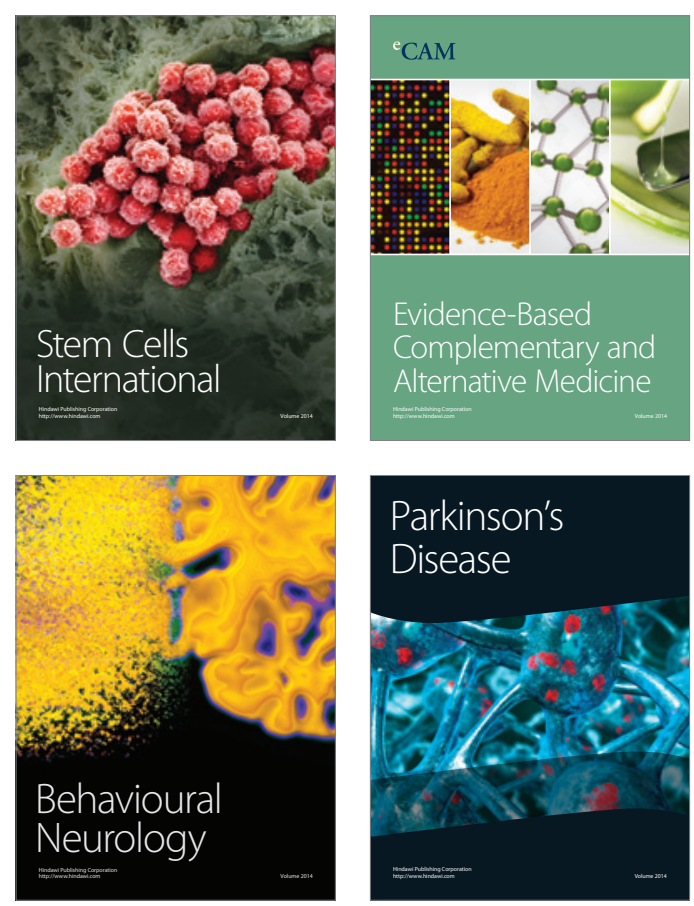

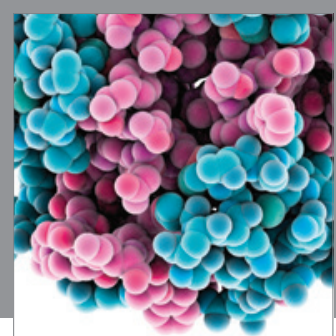

Journal of
Diabetes Research

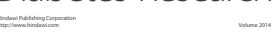

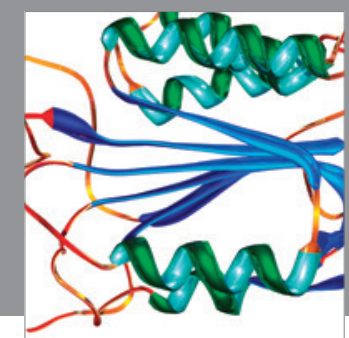

Disease Markers
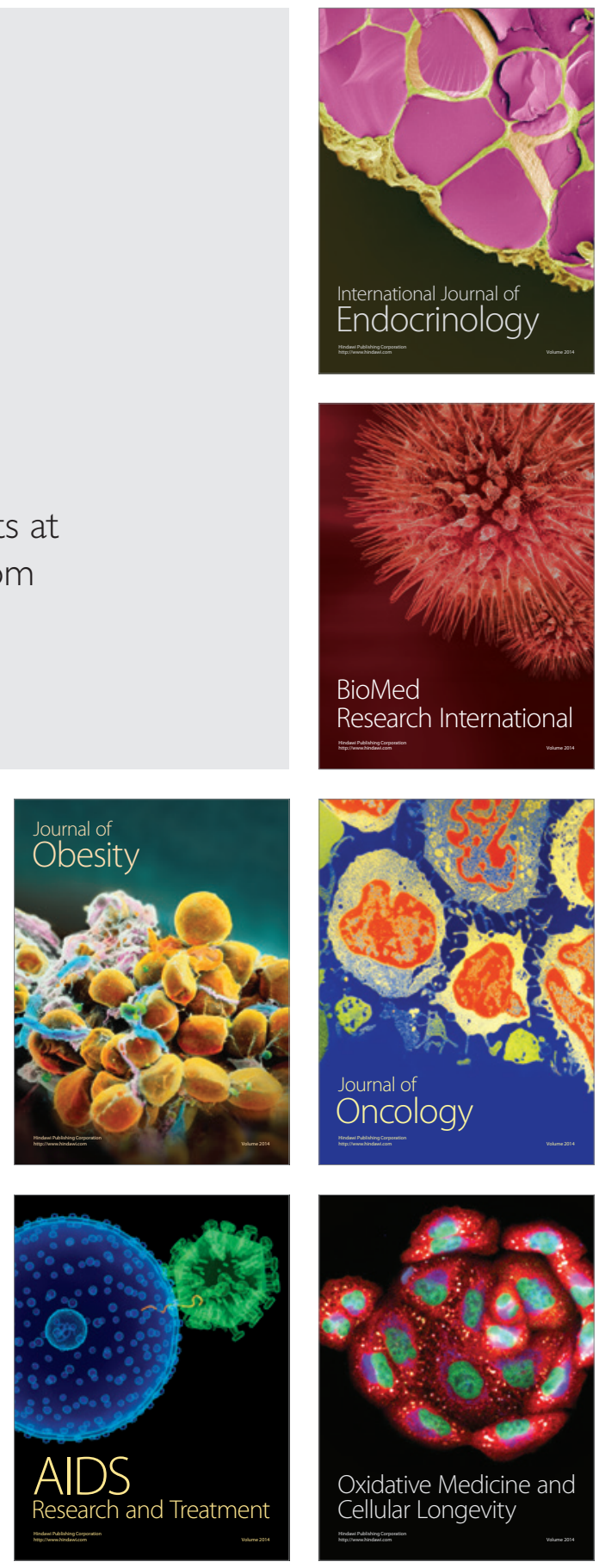